Research

\title{
Changes in the central component of the hypothalamus-pituitary-thyroid axis in a rabbit model of prolonged critical illness
}

\author{
Liese Mebis ${ }^{1}, Y_{v e s}$ Debaveye ${ }^{1}$, Björn Ellger ${ }^{1}$, Sarah Derde ${ }^{1}$, Eric-Jan Ververs ${ }^{1}$, Lies Langouche ${ }^{1}$, \\ Veerle M Darras ${ }^{2}$, Eric Fliers ${ }^{3}$, Theo J Visser ${ }^{4}$ and Greet Van den Berghe ${ }^{1}$
}

\author{
1Department of Intensive Care Medicine, Katholieke Universiteit Leuven, Herestraat 49, Leuven, B-3000, Belgium \\ 2Laboratory of Comparative Endocrinology, Katholieke Universiteit Leuven, Naamsestraat 61, Leuven, B-3000, Belgium \\ ${ }^{3}$ Department of Endocrinology and Metabolism, Academic Medical Center, University of Amsterdam, Meibergdreef 9, Amsterdam, 1105 AZ, The \\ Netherlands \\ ${ }^{4}$ Department of Internal Medicine, Erasmus University Medical Center, Dr. Molewaterplein 50, Rotterdam, 3015 GE, The Netherlands
}

Corresponding author: Greet Van den Berghe, greet.vandenberghe@med.kuleuven.be

Received: 25 Jun 2009 Revisions requested: 30 Jul 2009 Revisions received: 28 Aug 2009 Accepted: 11 Sep 2009 Published: 11 Sep 2009

Critical Care 2009, 13:R147 (doi:10.1186/cc8043)

This article is online at: http://ccforum.com/content/13/5/R147

(C) 2009 Mebis et al.; licensee BioMed Central Ltd.

This is an open access article distributed under the terms of the Creative Commons Attribution License (http://creativecommons.org/licenses/by/2.0), which permits unrestricted use, distribution, and reproduction in any medium, provided the original work is properly cited.

\begin{abstract}
Introduction Prolonged critically ill patients reveal low circulating thyroid hormone levels without a rise in thyroid stimulating hormone (TSH). This condition is labeled "low 3,5,3'tri-iodothyronine $\left(\mathrm{T}_{3}\right)$ syndrome" or "nonthyroidal illness syndrome (NTI)" or "euthyroid sick syndrome". Despite the low circulating and peripheral tissue thyroid hormone levels, thyrotropin releasing hormone $(\mathrm{TRH})$ expression in the hypothalamus is reduced and it remains unclear which mechanism is responsible. We set out to study whether increased hypothalamic $\mathrm{T}_{3}$ availability could reflect local thyrotoxicosis and explain feedback inhibition-induced suppression of the TRH gene in the context of the low $\mathrm{T}_{3}$ syndrome in prolonged critical illness.
\end{abstract}

Methods Healthy rabbits were compared with prolonged critically ill, parenterally fed animals. We visualized TRH mRNA in the hypothalamus by in situ-hybridization and measured mRNA levels for the type II iodothyronine diodinase (D2), the thyroid hormone transporters monocarboxylate transporter (MCT) 8, MCT10 and organic anion co-transporting polypeptide
1C1 (OATP1C1) and the thyroid hormone receptors $\alpha$ (TR $\alpha$ ) and $\beta$ (TR $\beta)$ in the hypothalamus. We also measured the activity of the D2 and type III iodothyronine deiodinase (D3) enzymes.

Results In the hypothalamus of prolonged critically ill rabbits with low circulating T3 and TSH, we observed decreased TRH mRNA, increased D2 mRNA and increased MCT10 and OATP1C1 mRNA while MCT8 gene expression was unaltered as compared with healthy controls. This coincided with low hypothalamic thyroxine $\left(T_{4}\right)$ and low-normal $T_{3}$ concentrations, without a change at the thyroid hormone receptor level.

Conclusions Although expression of D2 and of the thyroid hormone transporters MCT10 and OATP1C1 were increased in the hypothalamus of prolonged critical ill animals, hypothalamic $\mathrm{T}_{4}$ and $\mathrm{T}_{3}$ content or thyroid hormone receptor expression were not elevated. Hence, decreased TRH gene expression, and hereby low TSH and T3 during prolonged critical illness, is not exclusively brought about by hypothalamic thyrotoxicosis, and infer other TRH suppressing factors to play a role.

\section{Introduction}

Prolonged critically ill patients reveal a suppressed neuroendocrine function with low circulating levels of several anterior pituitary-dependent hormones [1]. The severity of these neu- roendocrine alterations was shown to be related to adverse outcome of patients in the intensive care unit $[1,2]$.

bp: base pair; BSA: bovine serum albumin; CV: coefficient of variation; D1: type 1 iodothyronine deiodinase; D2: type 2 iodothyronine deiodinase; D3: type 3 iodothyronine deiodinase; HPRT: hypoxanthine guanine phosphoribosyl transferase; HPT: hypothalamus-pituitary-thyroid; MCT: monocarboxylate transporter; OATP: organic anion transporting polypolypeptide; PCR: polymerase chain reaction; PN: parenteral nutrition; PVN: paraventricular nucleus; RIA: radioimmunoassay; T3: 3,5,3'-triiodothyronine; T4: thyroxine; TR: thyroid hormone receptor; TRH: thyrotropin releasing hormone; TSH: thyroid stimulating hormone, thyrotropin. 
The thyroid axis is driven by thyrotropin releasing hormone (TRH) from the paraventricular nucleus (PVN) of the hypothalamus. TRH stimulates the release of thyroid stimulating hormone or thyrotropin (TSH) from the pituitary, which in turn drives the thyroid gland to produce and release the prohormone thyroxine $\left(\mathrm{T}_{4}\right)$ and to a minor extent the active hormone $3,5,3$ '-triiodothyronine $\left(T_{3}\right) . T_{4}$ is metabolized in peripheral tissues to produce $T_{3}$. There is a typical negative feedback regulation from $T_{3}$ and $T_{4}$ at the level of the pituitary and the hypothalamus. During prolonged critical illness, circulating $T_{3}$ levels are low and in severe and prolonged cases, $T_{4}$ levels are also reduced [3]. This condition is referred to as the 'low $\mathrm{T}_{3}$ syndrome', the 'non-thyroidal illness syndrome' or the 'euthyroid sick syndrome', different names that reflect the uncertainty regarding its origin and clinical implications. Despite the low levels of circulating and peripheral tissue thyroid hormones, TRH expression in the hypothalamus is reduced [4] and the TSH secretory pattern shows a dramatic loss in pulsatility, which correlates positively with the low serum $\mathrm{T}_{3}$ concentrations $[1,3]$. The reduced $\mathrm{TSH}$ release seems to be secondary to the diminished drive by TRH [1]. It remains unclear which mechanism is responsible for the reduced hypothalamic TRH expression during prolonged critical illness.

Several mechanisms have been proposed for the suppression of the hypothalamus-pituitary-thyroid (HPT) axis during critical illness, among which is a local thyrotoxicosis in the hypothalamus. Increased hypothalamic $\mathrm{T}_{3}$ availability could indeed explain feedback inhibition-induced suppression of the TRH gene in the context of the low $T_{3}$ syndrome. $A$ first mechanism for increasing the local concentration of $T_{3}$ in the hypothalamus is increased local conversion of $\mathrm{T}_{4}$ to $\mathrm{T}_{3}$. More than $80 \%$ of $T_{3}$ in the brain originates from local $T_{4}$ to $T_{3}$ conversion by the type II iodothyronine deiodinase (D2) [5]. Therefore, an upregulation of D2 in the mediobasal hypothalamus could lead to a local hyperthyroid state which in turn would suppress TRH in hypophysiotropic neurons. Injection of lipopolysacharide in rats and mice has been shown to upregulate hypothalamic D2 expression and activity [6-9]. Alternatively, decreased inactivation of $T_{3}$ and $T_{4}$ by the type III iodothyronine deiodinase (D3) could also lead to higher hypothalamic thyroid hormone levels suppressing $\mathrm{TRH}$. In line with this, a mouse model for chronic inflammation showed decreased D3 mRNA expression in the region of the hypothalamic PVN [10].

A second possible mechanism by which local iodothyronine levels in the hypothalamus could be increased is elevated transport of iodothyronines into the hypothalamus. The entry of thyroid hormone from the circulation into the hypothalamus is mediated by specific thyroid hormone transporters of which two categories have been identified, organic anion transporters and amino acid transporters. $\mathrm{Na}^{+}$-independent organic anion co-transporting polypeptides (OATPs) represent a large family of homologous proteins of which OATP1C1 (SLCO1C1) shows a high specificity and affinity towards iodothyronines, in particular $\mathrm{T}_{4}$ and reverse $\mathrm{T} 3\left(\mathrm{rT}_{3}\right)[11,12]$. OATP1C1 is mainly expressed in brain capillaries and is considered to be important for the uptake of $\mathrm{T}_{4}$ across the bloodbrain barrier [11-13]. The human monocarboxylate transporter 8 (MCT8), a specific thyroid hormone transporter, is also expressed in the hypothalamus and transports $T_{4}$ and $T_{3}$ in a $\mathrm{Na}^{+}$-independent manner [14]. Study of MCT8 null-mice suggests that its expression is necessary for normal feedback regulation of TRH neurons in the hypothalamus $[15,16]$. MCT10 was identified as a T-type amino-acid transporter $[17,18]$ and was recently shown to be at least as active for thyroid hormone transport as MCT8 [19]. The role of these transporters in hypothalamic feedback regulation in critically ill patients is currently unknown.

The major effects of thyroid hormone are exerted by interaction with its nuclear receptors. Thereby, a third mechanism explaining a lower TRH expression in the face of normal or low thyroid hormone levels could be an increased activity of the available thyroid hormone by increasing the expression of the nuclear thyroid hormone receptors. No data on hypothalamic expression of the different thyroid hormone receptors in prolonged critical illness are currently available.

Our goal was to study if increased local $T_{3}$ content in the hypothalamus, brought about by these different potential mechanisms, suppresses hypophysiotropic TRH neurons during prolonged critical illness.

\section{Materials and methods In vivo animal experiment}

All animals were treated according to the Principles of Laboratory Animal Care formulated by the U.S. National Society for Medical Research and the Guide for the Care and Use of Laboratory Animals prepared by the National Institutes of Health. The study protocol was approved by the Leuven University ethical review board for animal research (P03052).

The model has been described in detail previously and is shown to reproduce the bi-phasic response to critical illness as seen in the human situation $[20,21]$.

Male New Zealand White rabbits were housed individually and exposed to artificial light for 14 hours per day. On day 1, rabbits were anesthetized with $30 \mathrm{mg} / \mathrm{kg}$ ketamine, intramuscularly (Merial, Lyon, France), and $0.15 \mathrm{mg} / \mathrm{kg}$ medetomidine, intramuscularly (Orion, Ospoo, Finland). Their neck and flanks were shaved and anesthesia was than supplemented by isoflurane (Isoba Vet; Schering-Plough, Brussels, Belgium) added to the breathing gas via regular vaporizer. Thereafter, a supplemental local paravertebral block with xylocaine 1\% (Astra Pharmaceuticals, Brussels, Belgium) was performed and a full-thickness burn injury equaling 15 to $20 \%$ total body surface area was imposed. At the end of the procedure, animals returned to their cages where overnight fluid resuscitation was 
started with a continuous infusion of Ringer's lactate at six drops per minute $( \pm 18 \mathrm{ml} / \mathrm{h})$ through a volumetric infusion pump (IVAC 531 infusion pump, IVAC cooperation, San Diego, CA, USA). All animals received parenteral nutrition (PN) from day 2 onwards to avoid starvation-induced endocrine alterations. The PN infusion bags contained $150 \mathrm{ml}$ of Clinomel N7 (Baxter, Clintec Parentéral, Maurepas, France) and $175 \mathrm{ml}$ sterile water. Thus, bags with $325 \mathrm{ml}$ solution contained $156 \mathrm{kcal}$ non-protein calories and $0.99 \mathrm{~g}$ nitrogen. Of all non-protein calories, $61.5 \%$ were delivered as carbohydrates, and $38.5 \%$ as fat. Protein intake equaled $1.49 \mathrm{~g} / \mathrm{kg}$ per day. No additional vitamins or trace elements were added. PN was infused at four drops a minute $( \pm 12 \mathrm{ml} / \mathrm{h})$. Animals had free access to water, but oral food intake was denied. Blood glucose levels were kept below $180 \mathrm{mg} / \mathrm{dl}$ by frequent blood glucose monitoring and titration of insulin infusion $(100 \mathrm{IU} / \mathrm{ml}$; Actrapid Novolet, Novo Nordisk, Bagsvaerd, Denmark; via an SE200B infusion pump, Vial Medical, Brezins, France) when necessary. In total, 25 animals survived 7 days of illness, after which blood was taken and serum was stored at $-20^{\circ} \mathrm{C}$. Animals were sacrificed and a tissue block containing the hypothalamus (rostral border just anterior of the optic chiasm, caudal border through the mamillary bodies, dorsal border through septum) was dissected and snap-frozen in liquid nitrogen. Healthy animals $(n=25)$, matched for gender, age, and body weight, that had free access to regular chow, were studied as controls.

\section{Serum analysis}

Plasma concentrations of TSH were measured by a specific radioimmunoassay (RIA; reagents provided by Dr. A. Parlow, National Pituitary Agency). The detection limit was $1.2 \mathrm{mIU} / \mathrm{l}$, and the intra assay coefficient of variation (CV) was $5.3 \%$. In one sample from a prolonged ill rabbit TSH was below the detection limit. Total concentrations of plasma $\mathrm{T}_{4}$ and $\mathrm{T}_{3}$ were determined by an in-house RIA [22]. The detection limit and intra assay CV were, 5 and $2 \mathrm{fmol}$ and $2.8 \%$ and $2.2 \%$, respectively. No free hormone determinations were performed because blood sampling was performed with heparinized catheters which is known to artefactually alter the free fraction of thyroid hormones in the samples [23].

\section{D2 and D3 activity}

The complete hypothalamic block of five control animals and six prolonged ill rabbits were homogenized on ice in 10 volumes of PED10 buffer (0.1 M phosphate, $2 \mathrm{mM}$ EDTA, $10 \mathrm{mM}$ DTT, pH 7.2) using a Polytron (Kinematica AG, Lucerne, Switzerland). Homogenates were cooled on ice and immediately analyzed. Protein concentration was measured with the BioRad Protein Assay (Bio-Rad, Veenendaal, The Netherlands) using BSA as the standard following the manufacturer's instructions. D2 and D3 activities were assayed [24] by duplicate incubations of homogenate (final protein concentration about $4 \mathrm{mg} / \mathrm{ml})$ for 60 minutes at $37^{\circ} \mathrm{C}$ with $\left.1 \mathrm{nM}\left[3^{\prime}, 5^{\prime}-125\right]\right] \mathrm{T}_{4}$ $(200,000 \mathrm{cpm})$ in a final volume of $0.1 \mathrm{ml}$ PED10 buffer. The incubations were carried out in the presence of $0.1 \mathrm{mM}$ propylthiouracil to inhibit possible D1 activity, and in the absence or presence of $0.1 \mu \mathrm{M}$ T3 to saturate D3 activity. Reactions were stopped by addition of $0.1 \mathrm{ml} 100 \%$ methanol on ice. After centrifugation, $0.1 \mathrm{ml}$ of the supernatant was added to $0.1 \mathrm{ml} 0.02 \mathrm{M}$ ammonium acetate $(\mathrm{pH} \mathrm{4.0)}$, and $0.1 \mathrm{ml}$ of the mixture was applied to a $4.6 \times 250 \mathrm{~mm}$ Symmetry C18 column connected to an Alliance high-performance liquid chromatography system (Waters, Etten-Leur, The Netherlands). The column was eluted with a linear gradient of acetonitrile (28 to $42 \%$ in 15 minutes) in $0.02 \mathrm{M}$ ammonium acetate $(\mathrm{pH} \mathrm{4.0)}$ at a flow of $1.2 \mathrm{ml} / \mathrm{min}$. The radio-activity in the eluate was measured on-line using a Radiomatic A-500 flow scintillation detector (Packard, Meriden, CT, USA). Activity eluting in the $\mathrm{T}_{3}$ and $\mathrm{rT}_{3}$ fractions represented $\mathrm{D} 2$ and $\mathrm{D} 3$ activity, respectively.

\section{Thyroid hormone concentration in the hypothalamus}

We used the hypothalamic block of 10 healthy rabbits and 11 prolonged critically ill rabbits to measure $T_{4}$ and $T_{3}$ content. lodothyronines were extracted and purified from the hypothalamus and $\mathrm{T}_{4}$ and $\mathrm{T}_{3}$ were measured by RIA, as described previously $[25,26]$. In brief, the entire hypothalamic block was homogenized directly in methanol, and $2000 \mathrm{cpm}$ of outer ring labeled [131]] $\mathrm{T}_{4}$ and [125I] $\mathrm{T}_{3}$ were added to each sample as internal tracers for recovery. Appropriate volumes of chloroform were added to extract with chloroform/methanol (2:1) twice. The iodothyronines were then back-extracted into an aqueous phase and purified by passing this aqueous phase through Bio-Rad AG $1 \times 2$ resin columns (Bio-Rad, Veenendaal, The Netherlands). After a pH gradient, the iodothyronines were eluted with 70\% acetic acid, evaporated to dryness, and resuspended in RIA buffer. The extracts were counted to determine the recovery of $\left[{ }^{131} 1\right] \mathrm{T}_{4}$ and $\left.\left[{ }^{125}\right]\right] \mathrm{T}_{3}$ added to each sample. For the present experiment the average recovery was $50.5 \%$ for $\left[{ }^{131} 1\right] \mathrm{T}_{4}$, and $74.5 \%$ for $\left.\left[{ }^{125}\right]\right] \mathrm{T}_{3}$. Concentrations were calculated using the amounts of $T_{4}$ and $T_{3}$ found in the respective RIAs, the individual recovery of [1311] $\mathrm{T}_{4}$ and [125I] $T_{3}$ added to each sample, and the weight of the tissue sample submitted for extraction.

\section{Cloning of rabbit genes}

Total RNA was isolated from rabbit hypothalamic tissue using Qiazol lysis reagent (Qiagen, Venlo, The Netherlands) and subsequently purified using the RNeasy mini RNA isolation kit (Qiagen, Venlo, The Netherlands). cDNA was obtained by reverse transcription of $2 \mu \mathrm{g}$ total RNA using random hexamer primers. Oligonucleotides homologous to sequences surrounding the start or stop codons of human, mouse and rat proTRH, D2, MCT8, MCT10, OATP1C1, thyroid hormone receptor (TR) $\alpha 1, T R \alpha 2, T R \beta 1$ and TR $\beta 2$ were designed and used for PCR. The amplified fragments were cloned into the PGEM-T vector followed by sequence analysis. These sequences showed high amino acid identity with the corresponding genes from other mammalian species and data have been submitted to the GenBank database: proTRH 
[GenBank:EF370408], D2 [GenBank:EU489480], MCT8 [GenBank:EF420874], MCT10 [GenBank:EF489851], OATP1C1 [GenBank:EF420875], TR 1 [GenBank:EU489476], TR $\alpha 2$ [GenBank:EU489477], TRß1 [GenBank:EU489478] and TRß2 [GenBank:EU489479]. Based on these sequences, we designed specific primers and probes for real-time PCR analysis and in situ hybridization.

\section{Fluorescence in situ hybridization}

TRH and D2 mRNA expression was analyzed in two healthy vs. two prolonged ill animals. The TRH and D2 in situ probes were generated in our laboratory. The TRH probe was complementary to 1 to $203 \mathrm{bp}$ of the rabbit proTRH mRNA sequence (EU489480), and the D2 probe was complementary to 3230 to $608 \mathrm{bp}$ of the rabbit type II deiodinase gene (EF370408). The fluorescent in situ hybridization protocol was adapted from a standard in situ hybridization protocol of the TSA ${ }^{\mathrm{TM}}$ Biotin System (New England Nuclear, Boston, MA). The antisense RNA probes were digoxin/digoxigenin labeled, diluted in hybridization buffer and hybridized on $10 \mu \mathrm{m}$ tissue cryosections overnight in a humidified stove at $62^{\circ} \mathrm{C}$. After washing, the sections were incubated with an anti-digoxin/digoxigenin horseradish peroxidase-labeled antibody. The probe was amplified using Tyramide Amplification Reagent (TSA ${ }^{\mathrm{TM}}$ Biotin System, NEN, Boston, MA), and visualized with streptavidine conjugated to Сy3. Following washes, the sections were mounted in Fluorescent Mounting Medium (DAKO, Glostrup, Denmark) with 4',6-diamidino-2-phenylindole (Sigma-Aldrich, Bornem, Belgium) to counter stain cell nuclei. We analyzed sense-probes as negative controls. As it is not possible to quantitate data obtained from fluorescent in situ hybridization with tyramide amplification, we attempted to do isotopic in situ hybridizations. This resulted in high background and low signal to noise ratio and results could not be used for analysis.

\section{RNA isolation and real-time PCR}

Gene expression analysis was performed on eight healthy rabbits vs. six prolonged ill animals. RNA was isolated from the total hypothalamic block using the RNeasy midi RNA isolation kit (Qiagen, Venlo, The Netherlands) and quantified by Nanodrop spectrophotometer (ND-1000, Nanodrop Technologies, Wilmington, DE, USA). Samples were treated with DNAse to remove all contaminating genomic DNA. A $1 \mu \mathrm{g}$ sample of total RNA was reverse-transcribed using random hexamers. All samples were reverse transcribed simultaneously. Reactions lacking reverse transcriptase were also run as a control for genomic DNA contamination.

D2, MCT8, MCT10, OATP1C1, TR $\alpha 1$, TR $\alpha 2$, TR $\beta 1$ and TR $\beta 2$ mRNA levels were quantified in real time with the ABI PRISM 7700 sequence detector (Applied Biosystems, Foster City, CA) which uses TaqMan chemistry for highly accurate quantization of mRNA levels. Sequences of the primers and probes are given in Table 1. The $10 \mu \mathrm{l}$ real-time reaction mixture contained $5 \mu \mathrm{l} \mathrm{TaqMan}{ }^{\circledR}$ Fast Universal PCR Master Mix (Applied
Biosystems, Foster City, CA), $0.5 \mu \mathrm{l}$ forward primer (18 $\mu \mathrm{M})$, $0.5 \mu \mathrm{l}$ reverse primer $(18 \mu \mathrm{M}), 0.5 \mu \mathrm{l} \mathrm{TaqMan}$ probe ([5']6FAM [3']BHQ-1 labeled) $(6 \mu \mathrm{M}), 0.5 \mu \mathrm{l}$ water and $3 \mu \mathrm{l}$ cDNA (7.5 ng). Unknown samples were run in duplicate and individual samples with a $\mathrm{Ct}$ value standard deviation greater than 0.3 were reanalyzed. Data were analyzed using the comparative $\mathrm{Ct}$ method. The rabbit hypoxanthine guanine phosphoribosyl transferase (HRPT) gene was first cloned and absolute quantification was performed using a standard curve. This showed no significant difference between healthy control and prolonged ill rabbits. HPRT was therefore used as an internal control.

\section{Statistical analysis}

All statistical analyses were done using StatView software (SAS Institute Inc., Cary, NC, USA). Data were analyzed using one-way analysis of variance tests. Data are presented as mean \pm standard deviation. Statistical significance was assumed for a two sided $P<0.05$.

\section{Results}

As described previously [21], this rabbit model of prolonged critical illness is characterized by low $\mathrm{T}_{3}$ plasma concentrations in the face of decreased TSH levels (Figure 1).

TRH is expressed at different sites in the hypothalamus; therefore, measuring TRH expression in homogenates of the total hypothalamic block would not selectively reflect hypophysiotropic TRH expression. We therefore used in situ hybridization histochemistry to visualize TRH mRNA expression and observed markedly reduced hybridization signal in the PVN of prolonged ill animals confirming the prolonged critically ill state of our animals. (Figures 2a, a', b and 2b').

D2 mRNA expression by in situ hybridization showed to be strongly increased in the mediobasal hypothalamus of prolonged ill animals, mostly in the floor and infralateral walls of the third ventricle (Figures 2b, b'). This increase was confirmed by quantitative real-time PCR measurement $(P=0.03$; Figure 3). D2 activity tended to be increased in sick rabbits but this did not reach significance (prolonged ill rabbits $0.14 \pm$ 0.09 vs. healthy controls $0.09 \pm 0.02, P=0.25$; Figure 3 ).

Incubation of hypothalamic homogenates with $\left[{ }^{125} \mid\right] T_{4}$ as described in Materials and Methods resulted in a 30 to $50 \%$ conversion of the substrate to $\left.\left[{ }^{125}\right]\right] \mathrm{r}_{3}$. Reverse $\mathrm{T}_{3}$ production was inhibited more than $80 \%$ by addition of $0.1 \mu \mathrm{M} \mathrm{T}_{3}$ to the incubation mixture, confirming that this represents D3 activity. D3 activity was not significantly different but tended to be higher in chronically ill rabbits (prolonged ill rabbits $1.63 \pm$ $0.45 \mathrm{fmol} / \mathrm{min} / \mathrm{mg}$ protein $v \mathrm{~s}$. healthy controls $1.24 \pm 0.34 ; P$ $=0.14)$.

Expression levels of thyroid hormone transporters MCT10 ( $P$ $=0.04)$ and OATP1C1 $(P=0.002)$ were significantly 
Table 1

\begin{tabular}{|c|c|c|}
\hline Gene name [Genbank accession number] & & Sequence \\
\hline \multirow[t]{3}{*}{ ocD2 [GenBank:EF370408] } & Forward: & 5'-GGACTCCGCTGTGTCTGGAA-3' \\
\hline & Probe: & 5'-CTTGACGCCTACAAACA-3' \\
\hline & Reverse: & 5'-GGCATCCTCGCCCAATTTT-3' \\
\hline \multirow[t]{3}{*}{ ocMCT8 [GenBank:EF420874] } & Forward: & 5'-CCATGTGGCCTTCTACTTTGC-3' \\
\hline & Probe: & 5'-CCCCCCATCATTGGAGCTGTCATC-3' \\
\hline & Reverse: & 5'-TGCATCAGAGGGACGAAGAAA-3' \\
\hline \multirow[t]{3}{*}{ ocMCT10 [Genbank:EF489851] } & Forward: & 5'-TCCGAGCAGAAATCCAATCG-3' \\
\hline & Probe: & 5'-TTGGGACACATCCCGGGCACC-3' \\
\hline & Reverse: & 5'-GGCTCCCATTGCCTTTGAG-3' \\
\hline \multirow[t]{3}{*}{ ocOATP1C1 [GenBank:EF420875] } & Forward: & 5'-GATCAGCGGTCTTTGGTTACCT-3' \\
\hline & Probe: & 5'-CTGTTCCTTTCCCTGTTTGCACTGGG-3' \\
\hline & Reverse: & 5'-TGCCACATCCAAGTTTTCACA-3' \\
\hline \multirow[t]{3}{*}{ ocTR $\alpha 1$ [GenBank:EU489476] } & Forward: & 5'-GAGTGCCCCACCGAACTCT-3' \\
\hline & Probe: & 5'-TCССССАСTСTTССTCGAGGTCTTTG-3' \\
\hline & Reverse: & 5'-CCGCCTGAGGCTTTTAGACTT-3' \\
\hline \multirow[t]{3}{*}{ ocTR $\alpha 2$ [GenBank:EU489477] } & Forward: & 5'-AAGTGCAGAGTTCGATTCTGTACAA-3' \\
\hline & Probe: & 5'-CGGGTCACTGGGCGTCCACC-3' \\
\hline & Reverse: & 5'-GAACAACATGCATTCCGAGAAG-3' \\
\hline \multirow[t]{3}{*}{ ocTRß1 [GenBank:EU489478] } & Forward: & 5'-GCGCAGCGCGTTGAA-3' \\
\hline & Probe: & 5'-AACGAACAGTCATCACCACATCTCATCCAG-3' \\
\hline & Reverse: & 5'-GGATGGAGCTCGTCCAAGTG-3' \\
\hline \multirow[t]{3}{*}{ ocTR $\beta 2$ [GenBank:EU489479] } & Forward: & 5'-GCCATCCTGACTATTTCACTGAAGA-3' \\
\hline & Probe: & 5'-AAGCCTACTTTTTTCTCAAGGGCAGTCACCG-3' \\
\hline & Reverse: & 5'-GGGATGTACCCTTTTTTCTGAGAGT-3' \\
\hline \multirow[t]{3}{*}{ ocHPRT [GenBank:AF020294] } & Forward: & 5'-TGTAGATTTTATCAGACTGAAGAGCTACTGT-3' \\
\hline & Probe: & 5'-TTTCCAGTTAAGGTTGAGAGATCATCTCCACCGAT-3' \\
\hline & Reverse: & 5'-AAGGAAAGCAAGGTCTGCATTGTT-3' \\
\hline
\end{tabular}

increased in the hypothalamus of prolonged ill animals (Figure 4a). There was no change in MCT8 gene expression (Figure 4a).

Hypothalamic TR $\alpha 1, T R \alpha 2, T R \beta 1$ and TR $\beta 2$ expression was not significantly different in prolonged ill animals as compared with healthy controls (Figure $4 b$ ).

In prolonged ill rabbits, we measured a $40 \%$ reduction in hypothalamic $\mathrm{T}_{4}$ content as compared with healthy rabbits ( $P$ $=0.03$, Figure 5 ). $\mathrm{T}_{3}$ content was not significantly different between the two groups, but tended to be lower in the critically ill animals $(P=0.17$, Figure 5$)$.

\section{Discussion}

Prolonged critical illness is hallmarked by reduced TRH gene expression in the face of low circulating $\mathrm{T}_{3}$ levels. In our animal model of prolonged critical illness, we investigated whether reduced $\mathrm{TRH}$ could be the result of feedback inhibition exerted by increased local $\mathrm{T}_{3}$ levels in the hypothalamus. We found increased D2 mRNA and increased thyroid hormone transporter gene expression (MCT10 and OATP1C1) in prolonged critically ill animals. These changes could lead to increased local $\mathrm{T}_{3}$ levels supporting our hypothesis. However, local $\mathrm{T}_{4}$ levels in the hypothalamus were lower in the critically ill than in healthy control animals, whereas local $\mathrm{T}_{3}$ levels were 
Figure 1

Plasma TT3 (nmol/l)

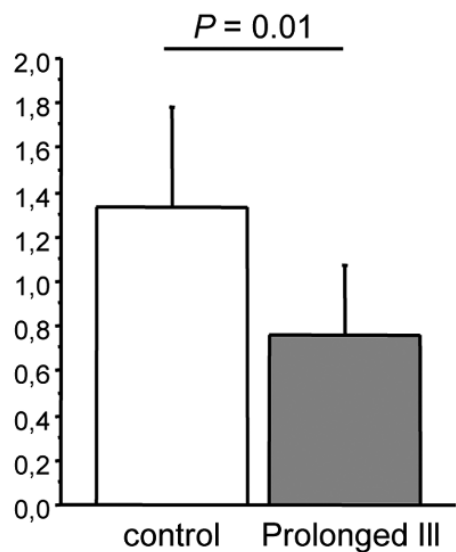

Plasma TT4 (nmol/l)

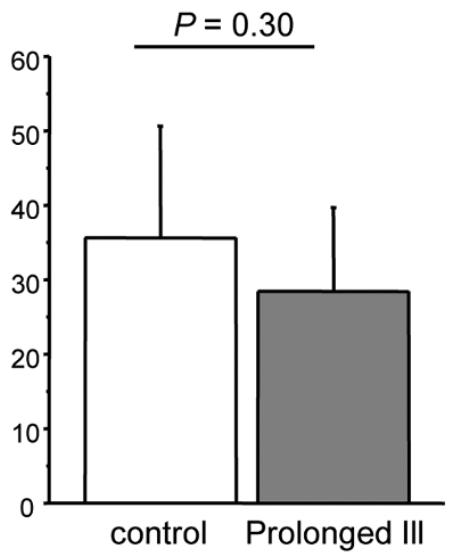

Plasma TSH (mU/l)

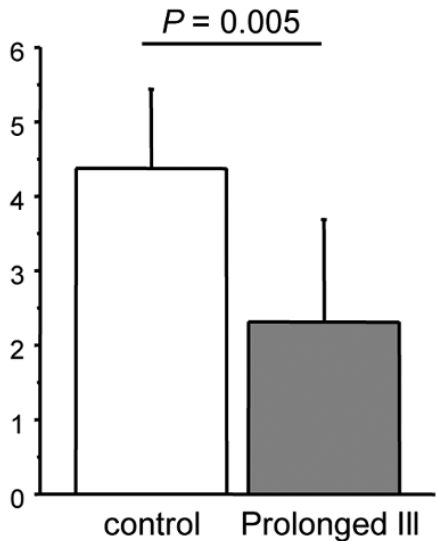

Circulating hormone parameters in healthy control $(n=10)$ and prolonged ill rabbits $(n=11)$. Data are expressed as mean \pm standard deviation. TT3 $=$ Total T3; TT $4=$ Total T4; TSH $=$ thyroid stimulating hormone.

similar. There was no change at the thyroid hormone receptor level.

By in situ hybridization staining we observed an almost complete loss of TRH signal in the PVN of prolonged ill animals. This confirms data from Fliers and colleagues who have clearly shown that TRH is reduced during prolonged critical illness [4].
D2 gene expression was markedly increased in the mediobasal hypothalamus in the prolonged critically ill state as was seen by in situ hybridization staining. This was confirmed when we quantified D2 gene expression levels with real-time PCR. We could not measure a significant difference in D2 activity levels although they seemed to have increased in prolonged critically ill animals. It is possible that this is due to a dilution effect because we measured deiodinases activity in the entire

Figure 2
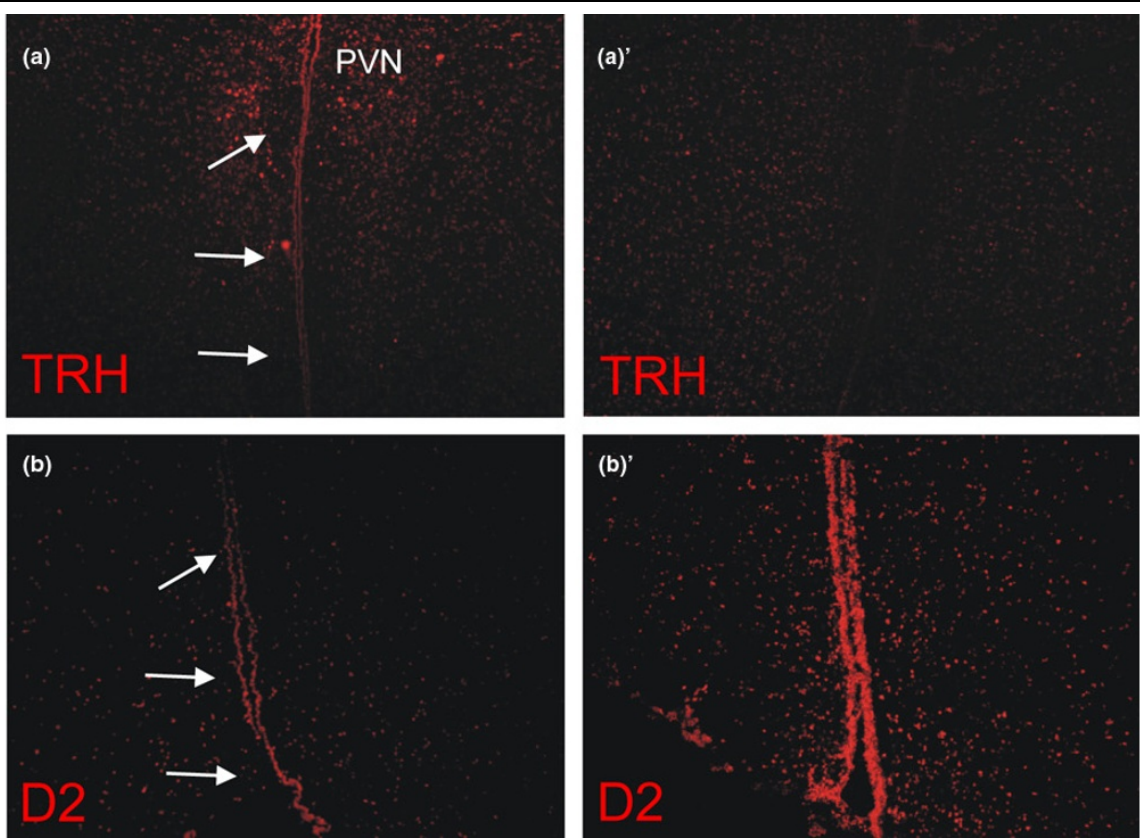

Fluorescence in situ hybridization staining for (a, $\left.\mathbf{a}^{\prime}\right) \mathrm{TRH}$, and (b, $\left.\mathbf{b}^{\prime}\right) \mathrm{D} 2$ on frozen sections of the hypothalamus. (a, b) Healthy control vs. (a', $\left.\mathbf{b}^{\prime}\right)$ prolonged ill animals. $\left(\mathbf{a}, \mathbf{a}^{\prime}\right)$ Magnification $\times 5,\left(\mathbf{b}, \mathbf{b}^{\prime}\right) \times 10 . \mathrm{D} 2=$ type II iodothyronine diodinase; $\mathrm{PVN}=$ paraventricular nucleus; TRH $=$ thyrotropin releasing hormone. Arrows represent third ventricle. 


\section{Relative D2 mRNA}

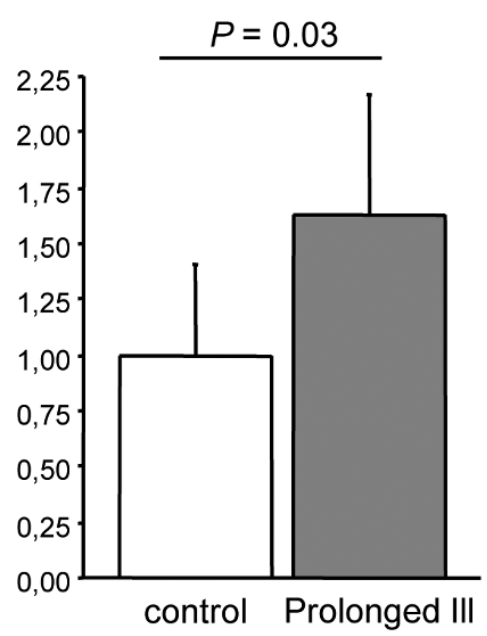

\section{D2 activity (fmol/min/mg)}

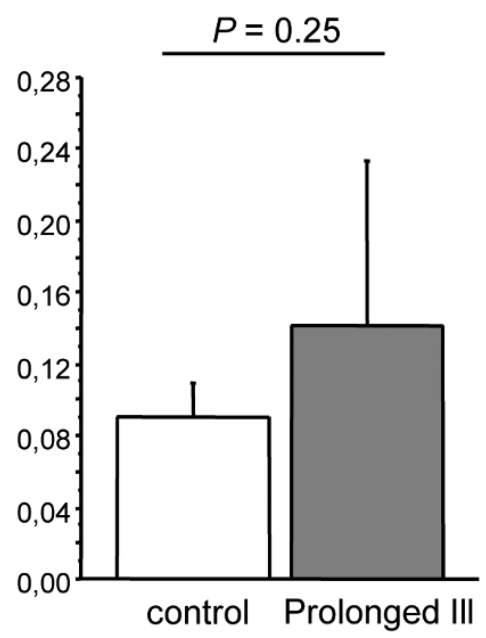

Relative D2 mRNA expression levels and D2 activity measured in the whole hypothalamus of healthy rabbits and prolonged ill rabbits. Healthy rabbits: $n=5$ for activity, $n=8$ for expression values; prolonged ill rabbits: $n=6$ for activity, $n=6$ for expression values. Data are expressed as mean \pm standard deviation. D2 = type II iodothyronine diodinase.

hypothalamic block. However, these results are very similar to those observed in hypothyroid animals where D2 gene expression was also found to be moderately increased without an overt increase in D2 activity [7]. In contrast, fasting has shown to evoke a more robust increase in D2 mRNA as well as activity levels [7]. A starvation-induced rise in D2 can be excluded in our model because all animals were fed via the parenteral route which guaranteed uptake of the delivered calories despite the anorexia accompanying illness. As Fekete and Lechan stated, relatively stable levels of D2 activity in the mediobasal hypothalamus is necessary for normal negative feedback regulation of the HPT axis. This allows hypophysiotropic TRH neurons to sense any changes in circulating $T_{4}$ levels [27].

A decrease in D3 activity is another possibility to increase local $\mathrm{T}_{3}$ levels. Hypothalamic D3 activity, however, showed an opposite change, because it was not reduced and even tended to be higher in sick animals.

We examined the expression of thyroid hormone transporters because an elevated transport of iodothyronines into the hypothalamus could also contribute to increased local $\mathrm{T}_{3}$ levels. MCT8 is expressed by neurons of the PVN, supraoptic, and infundibular nuclei [28] and analysis of two different knockout models showed the importance of MCT8 for thyroid hormone entry into the brain $[15,16]$. We observed no significant change in MCT8 gene expression during prolonged critical illness in our rabbit model. However, we measured an increase in MCT10 and OATP1C1 mRNA levels. Ramadan and colleagues showed low gene expression levels of MCT10 in total brain RNA extracts [29]. We are the first to show specific hypothalamic MCT10 expression. It was only very recently that MCT10 was shown to be a very active transporter of $T_{3}$ and, to a lesser extent, of $T_{4}$ [19]. The $T_{4}$-specific transporter OATP1C1 was previously shown to be regulated by thyroid hormone [13]. In hypothyroid rats, the expression of OATP1C1 is increased in brain capillaries and, conversely, hyperthyroid rats show decreased expression of this transporter. Regulation of OATP1C1 can thus be an adaptive response to protect hypothalamic thyroid hormone levels against fluctuating plasma levels.

Increased expression of thyroid hormone receptors is another way to increase thyroid hormone activity and thereby reducing TRH expression in the face of normal or low hypothalamic thyroid hormone levels, and expression of thyroid hormone receptor isoforms was shown to be regulated by thyroid hormone status in the hypothalamus [30]. However, our results did not support such a mechanism, because the expressions of TR $\alpha 1$, $\operatorname{TR} \alpha 2, \operatorname{TR} \beta 1$ and TR $\beta 2$ were unaltered in prolonged critically ill animals as compared with those in healthy controls.

Increased expression of D2 and increased expression of thyroid hormone transporters, as we observed in the prolonged critically ill rabbits, could theoretically lead to increased local $\mathrm{T}_{3}$ levels, explaining the suppressed TRH gene expression and the low circulating TSH levels. However, unexpectedly, local $\mathrm{T}_{3}$ concentrations were not increased and even tended to be low and hypothalamic $T_{4}$ content was significantly reduced in prolonged ill animals. Data on local levels of thyroid hormones in the hypothalamus during prolonged critical illness are 


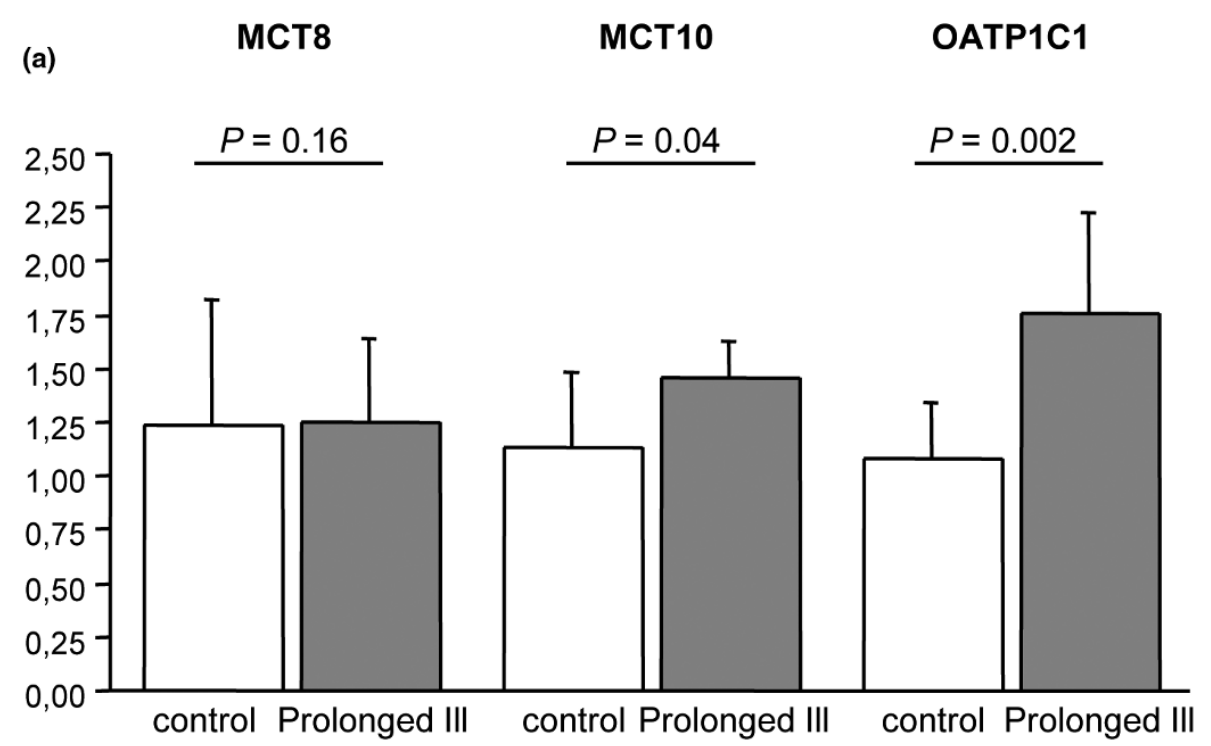

TRalfa1

(b)

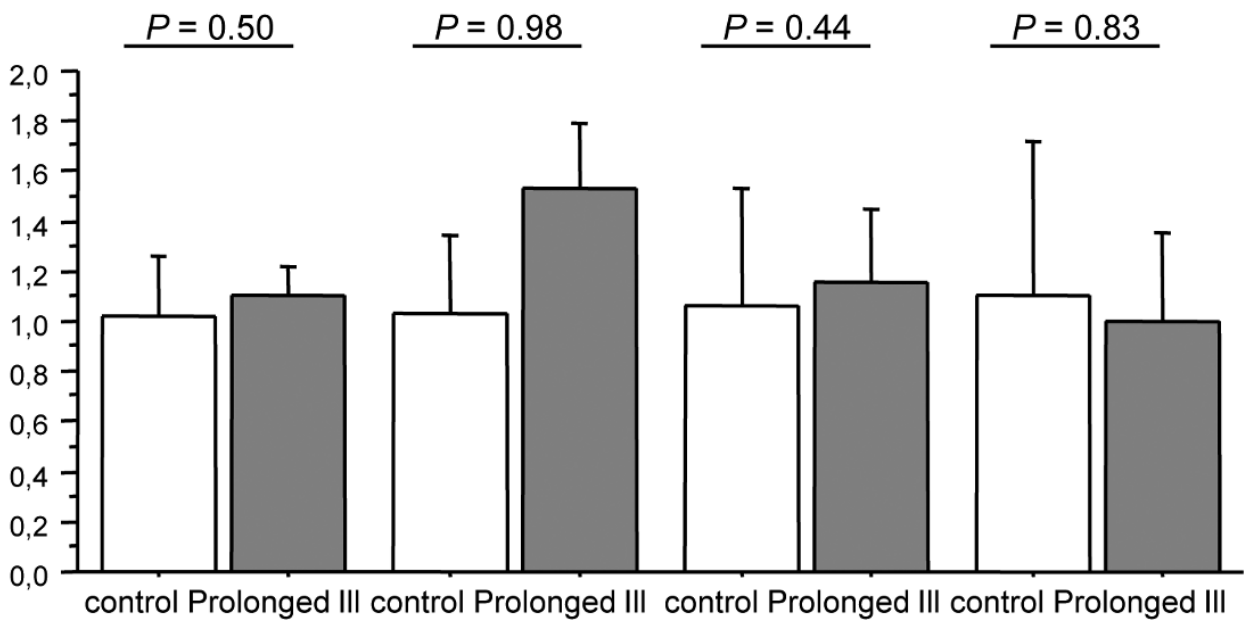

Relative mRNA expression of thyroid hormone transporters and thyroid hormone receptors measured in hypothalamus of healthy control and prolonged ill rabbits. (a) Thyroid hormone transporters measured were MCT8, MCT10 and OATP1C1 and (b) thyroid hormone receptors measured were TR $\alpha 1, T R \alpha 2, T R \beta 1$ and TR $\beta 2$ in hypothalamus of healthy control $(n=8)$ and prolonged ill rabbits $(n=6)$. Data are expressed as mean \pm standard deviation.

scarce. A study by Arem and colleagues showed that the hypothalamus of patients who died after chronic severe illness contains less than half the concentration of $\mathrm{T}_{3}$ as compared with patients who died from an acute trauma [31], which is in line with our data. There are two possible ways to interpret our findings. Because we measured iodothyronine concentrations in the entire hypothalamic block, we cannot exclude a dilution effect. Alternatively, local thyroid hormone content in the hypothalamus could indeed be low during prolonged critical illness. In that case, other mechanisms inferentially are respon- sible for reducing TRH gene expression during prolonged critical illness and the increased D2 and increased thyroid hormone transporter gene expression levels which we observed could reflect a compensatory response to a local hypothyroid state. Such a compensatory response would be in line with the upregulated D2 expression and activity documented in skeletal muscle of prolonged critically ill patients [32].

Some limitations of our study should be addressed. Our animal model of burn injury-induced critical illness may mirror only 


\section{T3 content Hypothalamus (pmol/g)}

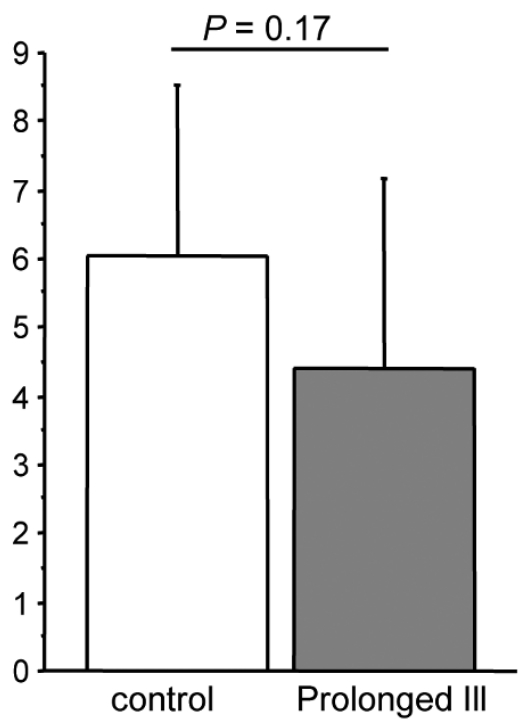

T4 content Hypothalamus (pmol/g)

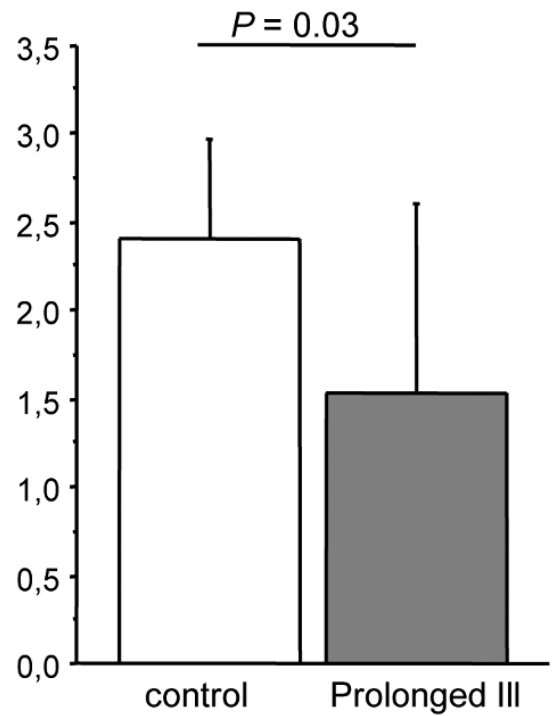

Local thyroid hormone concentrations in hypothalamus of healthy control $(n=10)$ and prolonged ill rabbits $(n=11)$. Data are expressed as mean \pm standard deviation. TT3 $=$ Total T3; TT4 $=$ Total T4

part of the complex entity of human critical illness, and thus extrapolating to the human situation or to other illnesses should be done with great caution. Secondly, we were only able to measure gene expression levels of thyroid hormone receptors and transporters. This does not necessarily reflect transporter activity levels.

\section{Conclusions}

In conclusion, although hypothalamic D2 mRNA and gene expression of the thyroid hormone transporters MCT10 and OATP1C1 were increased in our animal model of prolonged critical illness, we failed to detect an increase in local $\mathrm{T}_{3}$ levels. This suggests that the reduced hypothalamic TRH expression in our animal model of prolonged critical illness is not necessarily the exclusive result of feedback-inhibition by locally elevated $\mathrm{T}_{3}$ levels. Other illness-related factors could be inferred to suppress the TRH gene and the increased expression of thyroid hormone transporters (MCT10 and OATP1C1) and of D2 may reflect a compensatory response to a central hypothyroid state during prolonged critical illness.

\section{Competing interests}

The authors declare that they have no competing interests.
Key messages

- D2 mRNA and expression of thyroid hormone transporters MCT10 and OATP1C1 is increased in the hypothalamus of prolonged critically ill rabbits.

- Hypothalamic T3 and T4 levels are not increased in a rabbit model of prolonged critical illness.

- Reduced TRH gene expression in the context of nonthyroidal illness cannot be explained by negative feedback inhibition by locally elevated T3 levels.

\section{Authors' contributions}

LM carried out the molecular genetic studies, the fluorescence in situ hybridizations, and drafted the manuscript. YD, BE, SD, and EJV carried out the rabbit experiments. LL participated in the design of the study and helped to draft the manuscript. VMD carried out the serum analysis and measured thyroid hormone content in the hypothalamus. EF participated in the design of the study and assisted with the in situ hybridizations. TJV assisted with the cloning of all the rabbit genes. GVdB conceived of the study, and participated in its design and coordination and helped to draft the manuscript. All authors read and approved the final manuscript.

\section{Acknowledgements}

We wish to thank P. Wouters, I. Milants, W. Coopmans, E. Van Herck, W. Van Ham, I. Proven, and L. Noterdaeme for their excellent technical 
assistance. We are grateful to to E. Kaptein for the D2 activity measurements. This work was supported by the Research Fund - Flanders, Belgium (FWO) (G.025805), PhD-scholarship, Aspirantenmandaat to YD, the Research Fund of the University of Leuven (GOA/2007/14) and a research grant from the Innovative Medizinische Forschung (EL 610304) and from B. Braun Stiftung, Germany, to B. Ellger. B. Ellger is currently at Department of Anesthesiology and Intensive Care Medicine, University Hospital Münster, Münster, Germany. L. Langouche is a Postdoctoral Fellow for the FWO.

\section{References}

1. Berghe $G$ Van den, de Zegher F, Baxter RC, Veldhuis JD, Wouters $P$, Schetz M, Verwaest C, Vorst E Van der, Lauwers $P$, Bouillon $R$, Bowers CY: Neuroendocrinology of prolonged critical illness: effects of exogenous thyrotropin-releasing hormone and its combination with growth hormone secretagogues. J Clin Endocrinol Metab 1998, 83:309-319.

2. Peeters RP, Wouters PJ, van Toor H, Kaptein E, Visser TJ, Berghe G Van den: Serum 3,3',5'-triiodothyronine (rT3) and 3,5,3'-triiodothyronine/rT3 are prognostic markers in critically ill patients and are associated with postmortem tissue deiodinase activities. J Clin Endocrinol Metab 2005, 90:4559-4565.

3. Berghe $G$ Van den, de Zegher F, Veldhuis JD, Wouters P, Gouwy S, Stockman W, Weekers F, Schetz M, Lauwers P, Bouillon R, Bowers CY: Thyrotrophin and prolactin release in prolonged critical illness: dynamics of spontaneous secretion and effects of growth hormone-secretagogues. Clin Endocrinol (Oxf) 1997, 47:599-612.

4. Fliers E, Guldenaar SE, Wiersinga WM, Swaab DF: Decreased hypothalamic thyrotropin-releasing hormone gene expression in patients with nonthyroidal illness. J Clin Endocrinol Metab 1997, 82:4032-4036.

5. Crantz FR, Silva JE, Larsen PR: An analysis of the sources and quantity of 3,5,3'-triiodothyronine specifically bound to nuclear receptors in rat cerebral cortex and cerebellum. Endocrinology 1982, 110:367-375.

6. Boelen A, Kwakkel J, Thijssen-Timmer DC, Alkemade A, Fliers E, Wiersinga WM: Simultaneous changes in central and peripheral components of the hypothalamus-pituitary-thyroid axis in lipopolysaccharide-induced acute illness in mice. J Endocrinol 2004, 182:315-323.

7. Diano S, Naftolin F, Goglia F, Horvath TL: Fasting-induced increase in type II iodothyronine deiodinase activity and messenger ribonucleic acid levels is not reversed by thyroxine in the rat hypothalamus. Endocrinology 1998, 139:2879-2884.

8. Fekete C, Gereben B, Doleschall M, Harney JW, Dora JM, Bianco AC, Sarkar S, Liposits Z, Rand W, Emerson C, Kacskovics I, Larsen PR, Lechan RM: Lipopolysaccharide induces type 2 iodothyronine deiodinase in the mediobasal hypothalamus: implications for the nonthyroidal illness syndrome. Endocrinology 2004, 145:1649-1655.

9. Fekete C, Sarkar S, Christoffolete MA, Emerson $\mathrm{CH}$ Bianco AC, Lechan RM: Bacterial lipopolysaccharide (LPS)-induced type 2 iodothyronine deiodinase (D2) activation in the mediobasal hypothalamus $(\mathrm{MBH})$ is independent of the LPS-induced fall in serum thyroid hormone levels. Brain Res 2005, 1056:97-99.

10. Boelen A, Kwakkel J, Wiersinga WM, Fliers E: Chronic local inflammation in mice results in decreased TRH and type 3 deiodinase mRNA expression in the hypothalamic paraventricular nucleus independently of diminished food intake. J Endocrinol 2006, 191:707-714.

11. Pizzagalli F, Hagenbuch B, Stieger B, Klenk U, Folkers G, Meier PJ: Identification of a novel human organic anion transporting polypeptide as a high affinity thyroxine transporter. $\mathrm{Mol}$ Endocrinol 2002, 16:2283-2296.

12. Tohyama $K$, Kusuhara $H$, Sugiyama $Y$ : Involvement of multispecific organic anion transporter, Oatp14 (Slc21a14), in the transport of thyroxine across the blood-brain barrier. Endocrinology 2004, 145:4384-4391.

13. Sugiyama $D$, Kusuhara $H$, Taniguchi $H$, Ishikawa $S$, Nozaki $Y$, Aburatani $\mathrm{H}$, Sugiyama $\mathrm{Y}$ : Functional characterization of rat brainspecific organic anion transporter (Oatp14) at the blood-brain barrier: high affinity transporter for thyroxine. J Biol Chem $2003,278: 43489-43495$
14. Friesema EC, Ganguly S, Abdalla A, Manning Fox JE, Halestrap AP, Visser TJ: Identification of monocarboxylate transporter 8 as a specific thyroid hormone transporter. J Biol Chem 2003, 278:40128-40135.

15. Dumitrescu AM, Liao XH, Weiss RE, Millen K, Refetoff S: Tissuespecific thyroid hormone deprivation and excess in monocarboxylate transporter (mct) 8-deficient mice. Endocrinology 2006, 147:4036-4043.

16. Trajkovic M, Visser TJ, Mittag J, Horn S, Lukas J, Darras VM, Raivich $\mathrm{G}$, Bauer $\mathrm{K}$, Heuer $\mathrm{H}$ : Abnormal thyroid hormone metabolism in mice lacking the monocarboxylate transporter 8 . J Clin Invest 2007, 117:627-635.

17. Kim DK, Kanai $Y$, Chairoungdua $\mathrm{A}$, Matsuo $\mathrm{H}$, Cha $\mathrm{SH}$, Endou $\mathrm{H}$ : Expression cloning of a Na+-independent aromatic amino acid transporter with structural similarity to $\mathrm{H}+/$ monocarboxylate transporters. J Biol Chem 2001, 276:17221-17228.

18. Kim DK, Kanai Y, Matsuo H, Kim JY, Chairoungdua A, Kobayashi $\mathrm{Y}$, Enomoto A, Cha SH, Goya T, Endou H: The human T-type amino acid transporter-1: characterization, gene organization, and chromosomal location. Genomics 2002, 79:95-103.

19. Friesema EC, Jansen J, Jachtenberg JW, Visser WE, Kester MH, Visser TJ: Effective cellular uptake and efflux of thyroid hormone by human monocarboxylate transporter 10 . Mol Endocrinol 2008, 22:1357-1369.

20. Weekers F, Van Herck E, Coopmans W, Michalaki M, Bowers CY Veldhuis JD, Berghe G Van den: A novel in vivo rabbit model of hypercatabolic critical illness reveals a biphasic neuroendocrine stress response. Endocrinology 2002, 143:764-774.

21. Debaveye $Y$, Ellger B, Mebis L, Van Herck E, Coopmans W, Darras VM, Berghe G Van den: Tissue deiodinase activity during prolonged critical illness: effects of exogenous thyrotropinreleasing hormone and its combination with growth hormonereleasing peptide-2. Endocrinology 2005, 146:5604-5611.

22. Geyten S Van der, Eynde I Van den, Segers IB, Kuhn ER, Darras VM: Differential expression of iodothyronine deiodinases in chicken tissues during the last week of embryonic development. Gen Comp Endocrinol 2002, 128:65-73.

23. Schatz DL, Sheppard RH, Steiner G, Chandarlapaty CS, de Veber GA: Influence of heparin on serum free thyroxine. J Clin Endocrinol Metab 1969, 29:1015-1022.

24. Salvatore D, Bartha T, Harney JW, Larsen PR: Molecular biological and biochemical characterization of the human type 2 selenodeiodinase. Endocrinology 1996, 137:3308-3315.

25. Morreale de Escobar G, Pastor R, Obregon MJ, Escobar del Rey $\mathrm{F}$ : Effects of maternal hypothyroidism on the weight and thyroid hormone content of rat embryonic tissues, before and after onset of fetal thyroid function. Endocrinology 1985, 117:1890-1900.

26. Morreale de Escobar G, Calvo R, Escobar del Rey F, Obregon MJ: Thyroid hormones in tissues from fetal and adult rats. Endocrinology 1994, 134:2410-2415.

27. Fekete $C$, Lechan RM: Negative feedback regulation of hypophysiotropic thyrotropin-releasing hormone (TRH) synthesizing neurons: role of neuronal afferents and type 2 deiodinase. Front Neuroendocrinol 2007, 28:97-114.

28. Alkemade A, Friesema EC, Unmehopa UA, Fabriek BO, Kuiper GG, Leonard JL, Wiersinga WM, Swaab DF, Visser TJ, Fliers E: Neuroanatomical pathways for thyroid hormone feedback in the human hypothalamus. J Clin Endocrinol Metab 2005, 90:4322-4334.

29. Ramadan T, Camargo SM, Summa V, Hunziker P, Chesnov S, Pos $\mathrm{KM}$, Verrey F: Basolateral aromatic amino acid transporter TAT1 (Slc16a10) functions as an efflux pathway. J Cell Physiol 2006, 206:771-779.

30. Clerget-Froidevaux MS, Seugnet I, Demeneix BA: Thyroid status co-regulates thyroid hormone receptor and co-modulator genes specifically in the hypothalamus. FEBS Lett 2004 , 569:341-345.

31. Arem R, Wiener GJ, Kaplan SG, Kim HS, Reichlin S, Kaplan MM: Reduced tissue thyroid hormone levels in fatal illness. Metabolism 1993, 42:1102-1108.

32. Mebis L, Langouche L, Visser TJ, Berghe G Van den: The type II iodothyronine deiodinase is up-regulated in skeletal muscle during prolonged critical illness. J Clin Endocrinol Metab 2007, 92:3330-3333. 